\title{
Isolation and biochemical characterization of an endo-1,3- $\beta$-glucanase from Streptomyces sioyaensis containing a C-terminal family 6 carbohydrate-binding module that binds to 1,3- $\beta$-glucan
}

\author{
Tang-Yao Hong, ${ }^{1}$ Chun-Wei Cheng, ${ }^{1}$ Jenn-Wen Huang ${ }^{2}$ \\ and Menghsiao Meng ${ }^{1}$
}

Graduate Institute of Agricultural Biotechnology', and Department of Plant Pathology², National Chung Hsing University, 250 KuoKuang Rd, Taichung, Taiwan 40227

\author{
Author for correspondence: Menghsiao Meng. Tel: +886422840328 . Fax: +886422853527. \\ e-mail:mhmeng@dragon.nchu.edu.tw
}

\begin{abstract}
A gene encoding 1,3- $\beta$-glucanase was isolated from Streptomyces sioyaensis based on an activity plate assay. Analysis of the deduced amino acid sequence of the gene revealed that the matured 1,3- $\beta$-glucanase has two functional domains separated by a stretch of nine glycine residues. The $\mathbf{N}$-terminal domain shares sequence similarity with bacterial endo-1,3- $\beta$-glucanases classified in glycosyl hydrolase family 16 (GHF 16), while the C-terminal domain is a putative carbohydrate-binding module (CBM) grouped into CBM family 6. To characterize the function of each domain, both the full-length and the CBM-truncated versions of the protein were expressed in Escherichia coli and purified to homogeneity. Biochemical data suggest that the glycosyl hydrolase domain preferentially catalyses the hydrolysis of glucans with $1,3-\beta$ linkage, and has an endolytic mode of action. Binding assay indicated that the C-terminal CBM binds to various insoluble $\beta$-glucans $(1,3-1,1,1,4$ - and 1,4 linkages) but not to xylan, a primary binding target for most members of CBM family 6. The full-length and the CBM-truncated proteins had similar specific activity (units per mol of hydrolase domain) on soluble 1,3- $\beta$-glucan, whereas the former had much stronger specific activity on insoluble 1,3- $\beta$-glucans, suggesting that the C-terminal CBM enhances the activity of the $S$. sioyaensis $1,3-\beta$-glucanase against insoluble substrates, presumably by increasing the frequency of encounter events between the hydrolase domain and the substrate.
\end{abstract}

Keywords: endo-1,3- $\beta$-glucanase, $\beta$-1,3-glucanase, laminarinase, carbohydrate-binding module module

\section{INTRODUCTION}

The glucan endo-1,3- $\beta$-D-glucosidases, classified as endo-1,3- $\beta$-glucanases (EC 3.2.1.39) and exo-1,3- $\beta$-glucanases (EC 3.2.1.58), are widely distributed among higher plants, fungi and bacteria. This class of enzyme catalyses the hydrolysis of $1,3-\beta$-D-glucosidic linkages in $1,3-\beta$-D-glucan, which is the main constituent of fungal

Abbreviations: CBM, carbohydrate-binding module; GHF, glucosyl hydrolase family; LC/MS, liquid chromatography/mass spectrometry.

The GenBank accession number for the sequence reported in this paper is AF21741. cell walls and a major structural and storage polysaccharide (laminarin) of marine macro-algae. In plants, it may be involved in defence against pathogenic fungi through its ability to degrade fungal cell walls (Castresana et al., 1990; Grenier et al., 1993; Yi \& Hwang, 1997). In fungi, it may play a role in cell expansion, cell-cell fusion and spore release (de la Cruz et al., 1995). In bacteria, it is related to the assimilation of fungal cell walls as a food source (Watanabe et al., 1992). Recently, the first viral 1,3- $\beta$-glucanase, from chlorella virus PBCV-1, was described (Sun et al., 2000).

The genes encoding endo-1,3- $\beta$-glucanase have been cloned and sequenced from a variety of plants (Buc- 
ciaglia \& Smith, 1994; Chang et al., 1993; Chye \& Cheung, 1995; de Loose et al., 1988; Hudspeth et al., 1996; Oh \& Yang, 1995) and bacteria and archaea such as Bacillus circulans (Okada et al., 1995; Yahata et al., 1990), Oerskovia xanthineolytica (Cellulomonas cellulans) (Ferrer et al., 1996; Shen et al., 1991), Thermotoga neapolitana (Zverlov et al., 1997), Rhodothermus marinus (Spilliaert et al., 1994), Arthrobacter sp. (Doi \& Doi, 1986) and Pyrococcus furiosus (Gueguen et al., 1997). Although both types of enzyme catalyse the same glucanohydrolysis reaction, bacterial enzymes are classified in glycosyl hydrolase family 16 (GHF 16), while plant enzymes are grouped in GHF 17, based on differences in their amino acid sequences (Henrissat, 1991; Henrissat \& Bairoch, 1993).

$1,3-\beta$-Glucanase has several potential applications in biotechnology, such as utilization in the production of yeast extract (Ryan \& Ward, 1985), and of soluble 1,3$\beta$-glucans that could act as immunoactivators (Mohagheghpour et al., 1995; Rios-Hernandez et al., 1994). It also exhibits antifungal activity for disease protection in plants (Castresana et al., 1990; Grenier et al., 1993; Yi \& Hwang, 1997). Recently, we have isolated a Streptomyces sioyaensis strain that exhibits antagonism against several fungal pathogens such as Pythium aphanidermatum, Colletotrichum higginsianum, Acremonium lactucum and Fusarium oxysporum (Chen et al., 2000). To study the enzyme that may be used by this $S$. sioyaensis strain for the hydrolysis of fungal cell walls, we set out to clone the gene of $1,3-\beta$-glucanase from this bacterium and to characterize the recombinant gene product.

\section{METHODS}

Materials. The 1,3- $\beta$-Glucans laminarin (from Laminaria digitata), curdlan (from Alcaligenes faecalis) and zymosan A (from Saccharomyces cerevisiae) were purchased from Sigma; pachyman was prepared from commercial fruiting bodies of the basidiomycete Poria cocos. Xylan, carboxymethylcellulose (CMC) and glucans with other glucosidic linkages such as lichenan $(1,3-1,4-\beta-)$, cellulose $(1,4-\beta$ - $)$, amylose $(1,4-\alpha-)$ and $\beta$ cyclodextrin $(1,6-\beta-)$ were also purchased from Sigma.

Bacterial strains and plasmids. The $S$. sioyaensis strain was isolated from peat moss. Escherichia coli XL-1 Blue (recA1 end 1 1 gyrA96 thi-1 hsdR17 supE44 relA1 lac $\left[\mathrm{F}^{\prime}\right.$ proAB lacl ${ }^{\alpha} \mathrm{Z}$ M15 Tn10(Tet $\left.\left.{ }^{r}\right)\right]$ ) was used as the host cell for harbouring the DNA library, and E. coli CodonPlus ( $\mathrm{F}^{-}$omp T hsdS $\left[\mathrm{r}_{\mathrm{B}}^{-} \mathrm{m}_{\mathrm{B}}^{-}\right]$ $\mathrm{dcm}^{+} \mathrm{Tet}^{\mathrm{r}}$ gal endA Hte [argU proL $\left.\mathrm{Cam}^{\mathrm{r}}\right]$ ) (Stratagene) for protein expression. Plasmid pUC18 was used as a cloning and expression vector.

Isolation of an endo-1,3- $\beta$-glucanase gene from $S$. sioyaensis. The extraction and manipulation of DNA were performed by standard protocols (Sambrook et al., 1989). A chromosomal DNA library of $S$. sioyaensis was created by inserting Bam HIcut DNA fragments $(3-10 \mathrm{~kb})$ into pUC18. The DNA library was then introduced into E. coli XL-1 Blue cells, and the cells were selected for growing on Luria-Bertani (LB) agar plates containing ampicillin $\left(100 \mu \mathrm{g} \mathrm{ml}^{-1}\right)$, IPTG $(0 \cdot 25 \mathrm{mM})$ and X$\mathrm{Gal}(0 \cdot 004 \%, \mathrm{w} / \mathrm{v})$. White colonies were then transferred onto agar medium containing curdlan $(0 \cdot 2 \%, \mathrm{w} / \mathrm{v})$ and aniline blue $(0.005 \%, \mathrm{w} / \mathrm{v})$ for screening the $1,3-\beta$-glucanase-producing cells based on formation of a halo around the positive colony (Mahasneh \& Stewart, 1980).

Nucleotide sequence determination. Both strands of the entire $\sim 3.1 \mathrm{~kb}$ DNA fragment containing the coding region for 1,3- $\beta$-glucanase were sequenced on an ABI Prism 377-96 auto sequencer (Perkin-Elmer) with the BigDye terminator cycle sequencing ready reaction kit (Perkin-Elmer). The nucleotide sequence of the $3.1 \mathrm{~kb}$ DNA fragment and the deduced amino acid sequence of the endo-1,3- $\beta$-glucanase are deposited in GenBank with the accession number AF217415.

Construction of 1,3- $\beta$-glucanase expression vectors. A putative ORF of $1437 \mathrm{bp}$ was found within the cloned $\sim 3.1 \mathrm{~kb}$ DNA fragment. Primers 5'-GTCCGAATTCCCGAGAGG CCA-3' and 5'-CAGTTAAGCTTCTGGTGCAGCACGC-3' were designed to amplify the putative ORF in a $50 \mu \mathrm{l} \mathrm{PCR}$ reaction buffer containing primers $(0.32 \mu \mathrm{M}$ each), dNTP $(0.2 \mathrm{mM}$ each $)$ and 2.5 units $P f u$ polymerase. The sequences in italic within the primers are the engineered cutting sites of EcoRI and HindIII, respectively, while the underlined sequence represents the putative ribosome-binding site. The PCR thermocycling was carried out for 35 cycles $\left(94^{\circ} \mathrm{C}\right.$, $1 \mathrm{~min} ; 56{ }^{\circ} \mathrm{C}, 1 \mathrm{~min} ; 72{ }^{\circ} \mathrm{C}, 3.5 \mathrm{~min}$ ) followed by a $10 \mathrm{~min}$ extension at $72^{\circ} \mathrm{C}$. Another pair of primers, $5^{\prime}$-GTCCGAATTCCCGAGAGGCCA-3' and 5'-CCCGAAAGCTTGTCACCTGGACG-3', was used to amplify a $3^{\prime}$-deleted DNA fragment $(\sim 1.1 \mathrm{~kb})$ under the same PCR conditions as described above. The amplified DNA fragments were cut with HindIII and EcoRI and then inserted into pUC18, to become expression vectors for the full-length and the C-terminally truncated enzymes, respectively.

Expression of 1,3- $\beta$-glucanase. A 2-ml overnight culture of $E$. coli CodonPlus cells harbouring expression vector was transferred into $200 \mathrm{ml} \mathrm{LB}$ medium containing ampicillin $\left(100 \mu \mathrm{g} \mathrm{ml}^{-1}\right)$ and chloramphenicol $\left(34 \mu \mathrm{g} \mathrm{ml}^{-1}\right)$ and shaken vigorously at $37^{\circ} \mathrm{C}$. To induce the expression of recombinant proteins, IPTG was added to a final concentration of $0.25 \mathrm{mM}$ at a cell density of $\mathrm{OD}_{600} \sim 0.5$ and the cultivation was continued for $15 \mathrm{~h}$ at $32^{\circ} \mathrm{C}$. Cells were then harvested by centrifugation $(13000 \mathrm{~g}, 10 \mathrm{~min})$, suspended in hypertonic buffer $(20 \%$ sucrose, $33 \mathrm{mM}$ Tris $/ \mathrm{HCl} \mathrm{pH} 7 \cdot 0,0 \cdot 1 \mathrm{mM}$ EDTA) and then osmotically shocked by replacing the buffer with $0.5 \mathrm{mM} \mathrm{MgCl}_{2}$ as described by Nossal \& Heppel (1966) to obtain the periplasmic proteins.

Purification of the recombinant proteins. The periplasmic proteins in sodium acetate buffer $(\mathrm{pH} 4 \cdot 0,10 \mathrm{mM})$ were first applied to a HiTrap SP column (Pharmacia) that had been equilibrated with the same buffer. While most of the E. coli proteins adsorbed onto the column, the proteins with 1,3- $\beta$ glucanase activity came out directly. The sodium acetate buffer of the enzyme solution was then replaced with potassium phosphate buffer $(10 \mathrm{mM}, \mathrm{pH} 8 \cdot 0)$ and the solution applied to a HiTrap Q column (Pharmacia). The proteins adsorbed on the column were eluted with $\mathrm{NaCl}$-containing buffer in a stepwise manner. The activity of $1,3-\beta$-glucanase was found in three fractions after HiTrap Q chromatography. A degraded form of the enzyme with an apparent molecular mass of $37 \mathrm{kDa}$ (designated as Curd3) was found in the flowthrough fraction; another degraded enzyme with an apparent molecular mass of $41 \mathrm{kDa}$ (designated as Curd2) and the matured full-length enzyme (53 kDa, designated as Curd1) were eluted with buffer containing $50 \mathrm{mM}$ and $200 \mathrm{mM} \mathrm{NaCl}$, respectively. Both Curd 2 and Curd 3 were homogeneous after the HiTrap Q step. To further purify Curd1, the buffer of the enzyme was replaced with potassium phosphate buffer (50 mM, pH 8.0) containing $1 \mathrm{M}$ ammonium sulfate, and the mixture was applied to an octyl-Sepharose (Pharmacia) 
column. The hydrophobic column was washed with potassium phosphate buffer $(50 \mathrm{mM}, \mathrm{pH} 8 \cdot 0)$, and Curd1 was subsequently eluted with phosphate buffer $(50 \mathrm{mM}, \mathrm{pH} 8 \cdot 0)$ containing ethylene glycol $(60 \%, \mathrm{v} / \mathrm{v})$. The C-terminal carbohydrate-binding module (CBM)-truncated protein (designated as CT) was purified by the same procedure as used for Curd3. The authentic molecular masses of Curd1 and CT were subsequently determined by LC/MS.

$\mathrm{N}$-terminal amino acid sequence. The $\mathrm{N}$-terminal amino acid sequences of the proteins were determined with a gas-phase protein sequencer (Applied Biosystems, model 476A).

Enzyme activity assay. Unless otherwise stated, the standard activity assay for $1,3-\beta$-glucanase was carried out at $65^{\circ} \mathrm{C}$ for $5 \mathrm{~min}$, using $0.5 \%(\mathrm{w} / \mathrm{v})$ laminarin in $50 \mathrm{mM}$ sodium acetate buffer ( $\mathrm{pH}$ 5.5). The glucose equivalents released from enzyme reactions were determined colorimetrically by the dinitrosalicylic acid method (Wood \& Bhat, 1988). One unit of activity is defined as the amount of enzyme required to release $1 \mu \mathrm{mol}$ glucose equivalents $\mathrm{min}^{-1}$ under the reaction conditions described above. Protein concentration was determined by the Coomassie blue method (Bradford, 1976) using bovine serum albumin as the standard. To determine the kinetic constants, the initial velocity at varying laminarin concentration was measured, and the values of $K_{\mathrm{m}}$ and $V_{\max }$ were obtained from a Lineweaver-Burk plot.

Detection of 1,3- $\beta$-glucanase on SDS-PAGE by activity staining. The protein samples were heated at $96^{\circ} \mathrm{C}$ for $3 \mathrm{~min}$ in loading buffer before they were separated on SDS-PAGE $(10 \%, \mathrm{w} / \mathrm{v}$, acrylamide). The separated proteins were then renatured by soaking the gel successively once in potassium phosphate buffer $(50 \mathrm{mM}, \mathrm{pH} 7 \cdot 0)$ containing 2-propanol $(25 \%, \mathrm{v} / \mathrm{v})$, and twice in potassium phosphate buffer $(50 \mathrm{mM}$, $\mathrm{pH} 7 \cdot 0$ ). Each soaking lasted for $30 \mathrm{~min}$ at room temperature. The gel was then overlaid with an $8 \mathrm{~mm}$-thick agarose gel $(2 \%, \mathrm{w} / \mathrm{v})$ containing $0.5 \%(\mathrm{w} / \mathrm{v})$ pachyman. After $12 \mathrm{~h}$ incubation at $37^{\circ} \mathrm{C}$, the proteins on the polyacrylamide gel were visualized by Coomassie blue staining, and the agarose gel was stained with Congo red (Béguin, 1983). The activity of $1,3-\beta$-glucanase was evidenced by the formation of a clear band against the dark brownish background on the agarose gel.

Binding activity assays. Binding activity of the $1,3-\beta$-glucanase to insoluble polysaccharides was assessed by mixing $0.6 \mu \mathrm{g}$ of the purified enzymes with various insoluble polysaccharides $(2 \mathrm{mg})$ in $1.0 \mathrm{ml} 50 \mathrm{mM}$ sodium acetate buffer $\left(\mathrm{pH} \mathrm{5.5)}\right.$ at $4{ }^{\circ} \mathrm{C}$ for $1 \mathrm{~h}$. After centrifugation $(1000 \mathrm{~g}, 5 \mathrm{~min})$, the residual activity for laminarin hydrolysis in the supernatant was determined. A decrease of the enzymic activity in the supernatant indicates that a fraction of the enzyme is bound to the insoluble polysaccharides (Yamamoto et al., 1998).

The affinity electrophoresis method using polyacrylamide gels containing soluble polysaccharide (Tomme et al., 1996) was applied to analyse the binding potency of protein samples to soluble polysaccharides. To prepare polysaccharide-containing gels, soluble glucan (final concentration $0 \cdot 1 \%, \mathrm{w} / \mathrm{v}$ ) was added to the separating gel mixtures $(7.5 \%$ acrylamide) prior to polymerization. Lichenan and xylan were heated at $70{ }^{\circ} \mathrm{C}$ for $20 \mathrm{~min}$ and $100^{\circ} \mathrm{C}$ for $10 \mathrm{~min}$, respectively, to increase their solubility before they were added into separating gel mixtures. Native polyacrylamide gels, with and without polysaccharide, were polymerized side-by-side, separated by an internal spacer, within the same glass plates. Each protein sample $(2 \mu \mathrm{g})$ was loaded into gels, with and without polysaccharide, and run at $4^{\circ} \mathrm{C}, 80 \mathrm{~V}$, until the tracking dye was $2 \mathrm{~cm}$ from the bottom of the gel. After electrophoresis, proteins were visualized by Coomassie blue staining.
Detection of hydrolytic products. The hydrolytic products of laminarin after treatment with 1,3- $\beta$-glucanase were determined by TLC. The purified enzyme $(0.6 \mu \mathrm{g})$ and laminarin $(0.5 \%, \mathrm{w} / \mathrm{v})$ were incubated in $1 \mathrm{ml}$ sodium acetate buffer $(50 \mathrm{mM}, \mathrm{pH} 5 \cdot 5)$ at $65^{\circ} \mathrm{C}$ for various time intervals. The reaction was stopped by repeated extraction with phenol/ chloroform $(1: 1, \mathrm{v} / \mathrm{v})$. Each $10 \mu \mathrm{l}$ volume of the reaction products was then spotted on a silica plate (silica gel 60 , Merck), developed with ethyl acetate/acetic acid/water (2:1:1, by vol.) (Sakellaris et al., 1990), and visualized by $p-$ anisaldehyde (Fried \& Sherma, 1982).

\section{RESULTS}

\section{Cloning and sequence analysis of the endo-1,3- $\beta$ - glucanase gene}

The ability of $S$. sioyaensis to secrete $1,3-\beta$-glucanase was first demonstrated by the formation of a distinct halo around bacterial colonies grown on solid medium containing curdlan and aniline blue. To clone the gene encoding the 1,3- $\beta$-glucanase, the chromosomal DNA from $S$. sioyaensis was partially digested by BamHI, inserted into pUC18, and transformed into E. coli. The white colonies of transformants on agar plates containing X-Gal, IPTG and ampicillin were then screened for $1,3-\beta$-glucanase activity by growing cells on agar plates containing curdlan and aniline blue. One out of approximately 6000 white colonies was considered to be a positive clone as evidenced by the surrounding halo. This positive clone contains a $\sim 3 \cdot 1 \mathrm{~kb}$ DNA fragment from $S$. sioyaensis. Determination of the nucleotide sequence of the entire DNA fragment revealed an ORF which may encode a protein of 478 amino acids with a calculated molecular mass of $49 \mathrm{kDa}$.

Analysis of the deduced amino acid sequence of the ORF revealed that the $\mathrm{N}$ terminus of the putative 1,3- $\beta$ glucanase contains a typical signal peptide sequence and a predicted cleavage site for processing between Ala-48 and Ser-49 according to the method developed by von Heijne (1986). A similarity search based on the BLASTP program (Altschul et al., 1997) showed that the sequence following the signal peptide may represent a catalytic domain with $1,3-\beta$-glucanase activity classified in GHF 16 (Fig. 1a). The sequence at the $C$ terminus is predicted to form a potential CBM similar to members of CBM family 6 found in several xylanases (Fig. 1b). Between these two functional domains is a polyglycine sequence.

\section{Expression and purification of the $S$. sioyaensis 1,3- $\beta$ - glucanase}

To confirm that the ORF actually encodes a 1,3- $\beta$ glucanase, a DNA fragment containing the ORF was amplified by PCR and transferred into E. coli for protein expression. After induction with IPTG, the proteins in the periplasmic space were analysed for $1,3-\beta$-glucanase activity (Fig. 2). Surprisingly,1,3- $\beta$-glucanase activity was identified for proteins of at least three different sizes. The proteins with smaller sizes (Curd2 and Curd3) are presumably the degraded fragments of the matured full-length 1,3- $\beta$-glucanase (Curd1), since the E. coli host 
(a)

57 WSQVFLDDFDGAAGSSVNTANWQFDTGTSYPGGAGNWG--TGEVESMTSST SSiO 57 LLWSDEFDGAAGSAPNPAVWNHETGA------HGWG--NAELQNYTASR OXan 46 WRLIWHDEFEG---SEVNKEYWTFEKGNGIAYGIPGWG--NGELEYYAE-- Pfur 216 WQLVWSQEFDD---GVIDPNVWNFEIGNGHAKGTPGWG--NAELEYYTD-- Thea 425 LIWQDEFN---GTTLDTSKWNYETGYYLNNDPATWGWGNAELQHYTNS- BCir 30 WELVWSDEFD--YNGLPDPAKWDYDVGG------HGWG--NQELQYYTRAR Rmar

106 SNVSLDGNGDLIITPRRDASGNWTSGRIETTRTDFQPPAGGKLR------ SSiO 98 ANSALDGQGNLVITARRE-------GD--GSYTSARMTTQGKYQPQYGRI OXan 90 -NNTYIVNGTLVIEARKEIITDPNEGT--FLYTSSRLKTEGKVEFSPPVV Pfur 260 -KNAFVEN:3CLVIEARKEQVSD-EYGT--YDYTSARITTEGKFEIKYGKI Tnea 470 TONVYVODGKINIKAMNDSKSEPODPNRYAOYSSGKINTKDKLSLKYGR- BCir 71 IENARVGGGVLIIEARRE-----SYEGR--EYTSARLVTRGKASWTYGRF Rmar

150 VEARLQMPNVTGDAAAGYWPAFWMLGAPERGNYQNWPGVGELDIMENV139 -EARIQIPR-----GQGIWPAFWMLGG--SFPGT PWPSSGEIDIMENVG 137 VEARIKLPK-----GKGLWPAFWMLGS--NIREVGWPNCGEIDIMEFLG 306 -EIRAKLPK-----GKGIWPALWMLGN--NIGEVGWPTCGEIDIMEMLG 519 VDFRAKIPT----GDGVWPALTMT PKDSVYGT-WAASGEIDVMEARG 114 -EIRARLPS-----GRGTWPAIWML PDRQTYGSAYWPDNGEIDIMEHVG

198 QGLNKTWATMHCGTSPGG-PCNETSGIGNLTACPNTTCHSGLHTYTMEWDR 180 FEPHRVHGTVHGPGYSG----GSGITGMYQHPQGWS-FADT FHTFAVDWK179 HEPRTIHGTVHGPGYSG----SKGITRAYTLPEGVPDFTEDFHVFGIVWY347 HDTRTVLRTAHGPGYSG----GASIGVAYHLPEEVPDFSEDFHVFSIEWD561 RLPGSVSGTIH---FGGQWPVNQSSGGDYHFPEG-QTFANDYHVYSVVWE157 FNPDVVHGTVHTKAYNHL--LGTQRGGSIRVPTARTDF----HVYAIEWT-

248 SVSPEAIRFSVDGVTYQTVTANH---MDAVTWTNAT-NHGFFVILNVAMGG 225 ---PGEITWEVDGQOFHRVTRAS-VGANA--W---VFDQPFFLILNVAVGG OXan 225 ---PDKIK NYVDGTFYHEVTKEQ-VEAMGYEW---VFDKPFYIILNIAVGG Pfur 393 $\begin{array}{lll}607 & ---E D N I K W Y V D G K F F Y K V T N Q Q W Y S T A A P N N P N A P F D E P F Y L I M N L A V G G & B c i r \\ 201 & ---P E E I R W F V D D S L Y Y R F P N E R-L T N P E A D W R H W P F D Q P F H L I M N I A V-- & R m a r\end{array}$

(b)

340 TGDRDAYGQIQAESYDGQSGVATETTTDTGGGQDMGYLANGDWALYKGVNFG SSIO 248 ---RSAFSKIEAEEYNSLKSSTIQTIGTSDGGSGIGYIESGDYLVFNKINFG Cthe 247 ---RDAFSIIEAEEYNSTNSSTLQVIGTPNNGRGIGYIENGNTVTYSNIDFG Cste 414 419 -

392 STPATQFYGRVASGAGGGVSGLVEVRLDSRTNAPIGSEAVGDTGGWQSW-- Ssio 297 N-GANSFKARVASGADTPTN--IQLRLGSPTGTLIGTLTVASTGG---wNN Cthe 296 S-GATGFSATVAT--EVNTS--IQIRSDSPTGTLLGTLYVSSTGS---WNT Cste 427 SAGAKTFKANVAT-NVGGN---IEVRLDSETGPLVGSLKVPSTGGMOTW-- BDO 434 SDGAIGFIARASSGTGGGN---IEIRLDSKDGPKVGTLNVEGTGD---WNQ BCiI

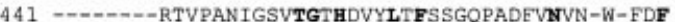
$342-\cdots-Y$ - 2 333 472 479 YIDAVTLLKDDQGAPSTITGVHDVYLVFTKTNDDYLFNLN-W-VKE

Fig. 1. (a) Partial alignment of the $S$. sioyaensis enzyme with other 1,3- $\beta$-glucanases of GHF 16 . Ssio, Streptomyces sioyaensis: Oxan, Oerskovia xanthineolytica (Cellulomonas cellulans); Pfur, Pyrococcus furiosus; Tnea, Thermotoga neapolitana; Rmar, Bcir, Bacillus circulans; Rhodothermus marinus. Sequences were taken from the following accession numbers: $O$. xanthineolytica $\beta$-1,3-glucanase Ila (U56935); $P$. furiosus endo- $\beta$-1,3-glucanase (AF013169); T. neapolitana laminarinase (Z47974); B. circulans $\beta$-1,3-glucanase A1 precursor (P23903); $R$. marinus laminarinase (AF047003). The conserved residues among bacterial 1,3- $\beta$ glucanases are indicated in boldface. (b) Partial alignment of the C-terminal CBM of the S. sioyaensis enzyme with several CBMs found in xylanases. Cthe, Clostridium thermocellum; Cste, Clostridium stercorarium; Bpol, Bacillus polymyxa; Bcir, Bacillus circulans. The sequences were deduced from the following accession numbers: $C$. thermocellum xylanase A (AF047761) $C$. stercorarium endo-1,4- $\beta$-xylanase (D13325); $B$. polymyxa endo-1,4- $\beta$-xylanase (X57094); $B$. circulans $\alpha-1,6$-mannanase (AB024331). The conserved residues are indicated in boldface.

does not have its own 1,3- $\beta$-glucanase. A DNA fragment containing a 3 '-deleted ORF was amplified by PCR and transferred into E. coli. This shorter ORF is assumed to encode a C-terminally truncated $1,3-\beta$-glucanase (CT,

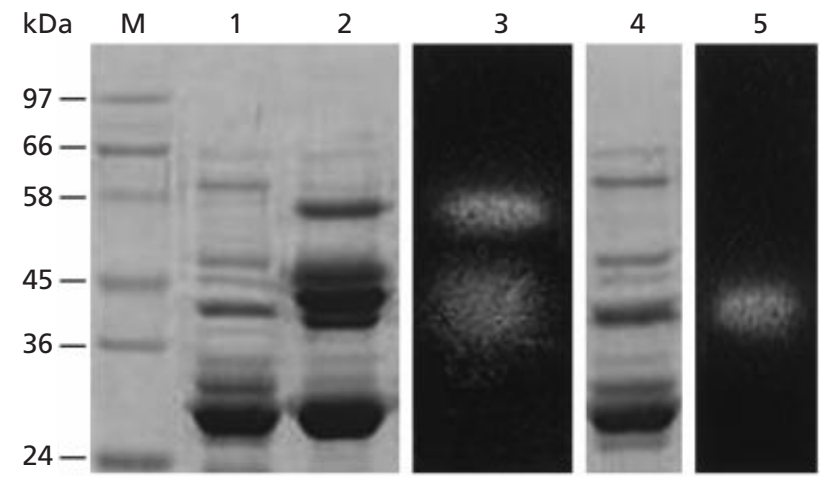

Fig. 2. Expression of the $S$. sioyaensis $1,3-\beta$-glucanase. Proteins in the periplasm of $E$. coli were analysed by $10 \%$ SDS-PAGE (lanes 1, 2 and 4), and the glucanase activity was determined by activity staining on the replica agarose gels (lanes 3 and 5). Lane 1, sample from $E$. coli cells harbouring vector plasmid pUC18. Lanes 2 and 4, samples from cells containing the intact and the 3 '-deleted ORF of the 1,3- $\beta$-glucanase gene, respectively. Lanes 3 and 5, replicas of lane 2 and 4, respectively. The molecular masses of protein markers (M) are shown on the left.

325 amino acids) that no longer contains the potential CBM. After induction with IPTG, the deleted ORF produced only one periplasmic protein exhibiting $1,3-\beta$ glucanase activity (Fig. 2). The above results indicate that the cloned $S$. sioyaensis gene indeed encodes a 1,3$\beta$-glucanase and that the signal peptide was able to direct the enzyme into the periplasm of E. coli cells. If the signal peptide was processed exactly at the predicted cutting site, the molecular masses of Curd1 and CT should be 44.6 and $29.4 \mathrm{kDa}$, respectively, which are smaller than the apparent molecular masses estimated from SDS-PAGE (Fig. 2).

A purification procedure was set up to purify the E. coliexpressed 1,3- $\beta$-glucanase. Curd3 (apparent molecular mass $37 \mathrm{kDa}$ ) and Curd2 (apparent molecular mass $41 \mathrm{kDa}$ ) could be purified by SP and Q column chromatography, while Curd1 (apparent molecular mass $53 \mathrm{kDa}$ ) could be purified by an additional hydrophobic interaction column step (Fig. 3). The yields of the enzymic activity were $20 \%$ for Curd3, 25\% for Curd 2 and $15 \%$ for Curd1, taking the total activity in the periplasm as $100 \%$. CT could be purified by the same procedure as Curd3 and they had similar apparent molecular masses on SDS-PAGE (Fig. 3). The identical amino acid sequence at the $\mathrm{N}$ termini (SAPAPPSGWSQVFLD---) of Curd1, Curd2 and Curd3 suggests that (1) the signal peptide was processed at the predicted site, and (2) Curd2 and Curd3 resulted from the removal of the C-terminal sequence by E. coli proteinase. To resolve the inconsistent molecular mass observed on SDSPAGE, the purified Curd1 and CT were subjected to LC/MS, and their authentic molecular masses were measured to be 44.611 and $29.366 \mathrm{kDa}$, respectively, consistent with the calculated values. The $S$. sioyaensis glucanase therefore must have an unusual shape which causes a decreased motility during electrophoresis. 
(a)

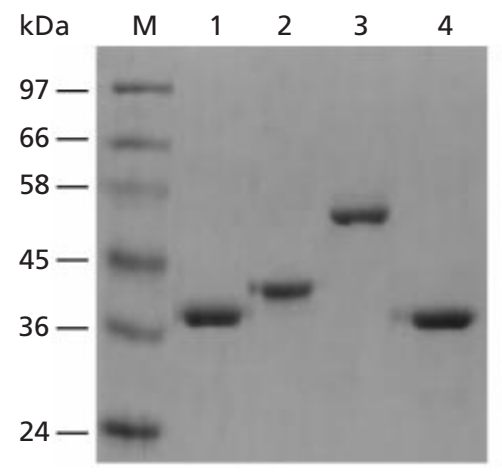

(b)

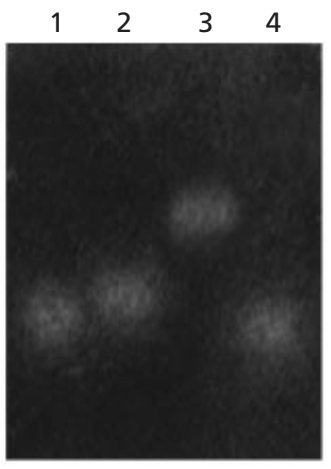

Fig. 3. Purification of the recombinant $1,3-\beta$-glucanase. (a) Recombinant proteins purified based on glucanase activity as described in Methods. Proteins in lanes 1 (Curd3), 2 (Curd2) and 3 (Curd1) were from cells containing the intact ORF of the 1,3$\beta$-glucanase gene, while lane 4 (CT) was from cells containing the 3'-deleted ORF. Curd 2 and Curd3 are assumed to be the degraded products of Curd1, and $\mathrm{CT}$ is a truncated protein without the C-terminal CBM. (b) Activity staining of the purified proteins on a replica agarose gel.

\section{Characterization of enzyme properties}

The general properties including the optimal working $\mathrm{pH}$ and temperature of the isolated 1,3- $\beta$-glucanase from $S$. sioyaensis were investigated with laminarin as the substrate. Over the investigated $\mathrm{pH}$ range $($ glycine $/ \mathrm{HCl}$, $\mathrm{pH} 3$; sodium acetate, $\mathrm{pH} 4-6$; potassium phosphate, $\mathrm{pH} 7-8$; glycine/ $\mathrm{NaOH}, \mathrm{pH} 9$ ), the enzyme exhibited optimum activity at $\mathrm{pH} 5 \cdot 5$. It was most active at $75^{\circ} \mathrm{C}$ for a 5 min reaction at $\mathrm{pH} 5.5$. The half-life of the enzyme was $\sim 70 \mathrm{~min}$ at $70^{\circ} \mathrm{C}$. Similar activity-pH profiles and temperature dependence were observed for Curd1, Curd2, Curd3 and CT.

To examine the substrate specificity of the $1,3-\beta$ glucanase, various polysaccharides were tested at a concentration of $5 \mathrm{mg} \mathrm{ml}^{-1}$. The results (Table 1) showed that 1,3- $\beta$-glucans (including laminarin, curdlan and pachyman) were the most favourable substrates, while $1,3-1,4-\beta$-glucan (lichenan) was hydrolysed to a lesser extent. It should be noted that lichenan needs to be pretreated $\left(70{ }^{\circ} \mathrm{C}, 20 \mathrm{~min}\right)$ to be hydrolysed by the $S$. sioyaensis enzyme. Zymosan A was a relatively poor substrate among the $\beta$-1,3-glucans tested. The enzyme did not show detectable activity against the remaining polysaccharides.

The specific activity [units (nmol protein) $)^{-1}$ ] of CT on soluble $\beta$-1,3-glucan (laminarin) was slightly higher than that of Curd1. The $K_{\mathrm{m}}$ values were determined to be 9 and $15 \mathrm{mg} \mathrm{ml}^{-1}$, respectively, for CT and Curd1, suggesting that the C-terminal CBM may have a negative influence on the catalytically relevant binding of laminarin. The respective $V_{\max }$ values were 96 and 79 units (nmol protein $)^{-1}$ for Curd1 and CT. On the other hand, Curd1 had much stronger specific activity than CT on insoluble substrates (curdlan and pachyman), implying that the C-terminal CBM plays a positive role in the hydrolysis of such substrates. Curd 2 and Curd3 behaved similarly to CT with respect to substrate specificity and specific activity (data not shown).

To determine the mode of action, the digested products of laminarin were analysed by TLC (Fig. 4). Initially, products larger than laminaribiose appeared. As the reaction proceeded, glucose and laminaribiose gradually accumulated. Curd1, Curd2, Curd3 and CT all had similar patterns (data not shown). This demonstrates that the $S$. sioyaensis enzyme is an endo-1,3- $\beta$-glucanase.

\section{Polysaccharide-binding activity of the C-terminal CBM}

Two approaches were taken to explore the polysaccharide-binding function of the C-terminal CBM. In the first, the purified enzymes were incubated with various insoluble polysaccharides at $4{ }^{\circ} \mathrm{C}$ for $1 \mathrm{~h}$, and the residual enzymic activity in the supernatant was then

Table 1. Substrate specificity of the Streptomyces sioyaensis $1,3-\beta$-glucanase

The enzymic reaction was carried out at $65^{\circ} \mathrm{C}$ for $5 \mathrm{~min}$ by incubating $0.5 \mu \mathrm{g}$ purified enzyme with $0.5 \%(\mathrm{w} / \mathrm{v})$ substrate in a final $1 \mathrm{ml}$ buffer solution. Curd 1 is the matured full-length $1,3-\beta-$ glucanase; CT is a C-terminally truncated enzyme without the CBM domain. The results are means of three independent experiments, with SD in parentheses. ND, No detectable activity. No activity was detected with cellulose, CMC, xylan, amylose, starch or $\beta$-cyclodextrin (data not shown).

\begin{tabular}{|c|c|c|c|}
\hline \multirow[t]{2}{*}{ Substrate } & \multirow[t]{2}{*}{ Main linkage (monomer) } & \multicolumn{2}{|c|}{ Specific activity [units nmol protein $\left.)^{-1}\right]$} \\
\hline & & Curd1 & CT \\
\hline Laminarin & $1,3-\beta$-(glucose) & $24 \cdot 0(1 \cdot 9)$ & $27 \cdot 7(1 \cdot 5)$ \\
\hline Curdlan & $1,3-\beta$-(glucose) & $50 \cdot 7(1 \cdot 5)$ & $19 \cdot 0(1 \cdot 9)$ \\
\hline Pachyman & $1,3-\beta-$ (glucose) & $27 \cdot 3(1 \cdot 6)$ & $17 \cdot 3(1 \cdot 6)$ \\
\hline Zymosan A & $1,3-\beta$-(glucose) & $5 \cdot 0(0 \cdot 3)$ & $3 \cdot 1(0 \cdot 6)$ \\
\hline Lichenan* & $1,3-1,4-\beta-($ glucose $)$ & $8 \cdot 4(0 \cdot 7)$ & $6 \cdot 1(0 \cdot 9)$ \\
\hline
\end{tabular}

* Lichenan was heated at $70{ }^{\circ} \mathrm{C}$ for 20 min before the enzymic reaction took place. Activity against lichenan was not detectable without the pretreatment. 


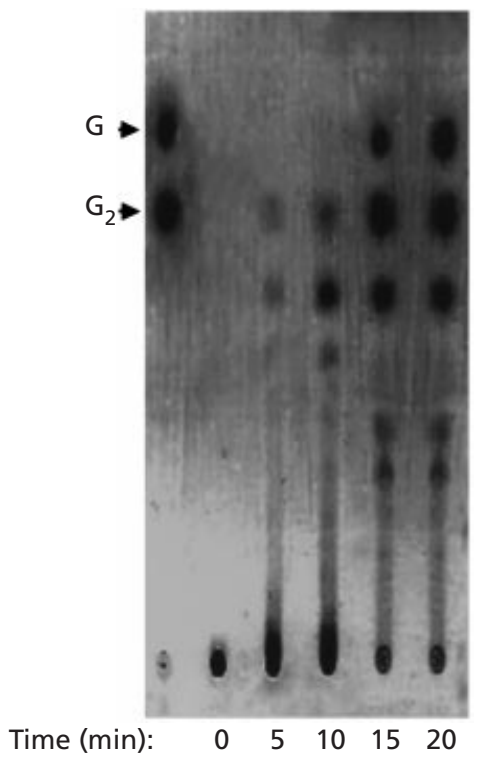

Fig. 4. Analysis of the digestion products of laminarin by TLC. Laminarin was subjected to hydrolysis by Curd 1 at $65^{\circ} \mathrm{C}$ for the indicated times. The reaction products were then analysed as described in Methods. Glucose $(G)$ and laminaribiose $\left(G_{2}\right)$ were used as standards.

Table 2. Binding of 1,3- $\beta$-glucanase to insoluble polysaccharides

The binding assay was carried out by mixing purified enzymes with various insoluble polysaccharides at $4{ }^{\circ} \mathrm{C}$ for $1 \mathrm{~h}$ as described in Methods. The enzymic activity against laminarin remaining in the supernatant was determined and compared to the original activity of each enzyme preparation, and is shown as recovered enzyme activity (\%). Data are means of three independent experiments.

\begin{tabular}{|lcccc|}
\hline Polysaccharide & \multicolumn{4}{c|}{ Recovered enzyme activity (\%) } \\
\cline { 2 - 5 } & Curd1 & Curd2 & Curd3 & CT \\
\hline Curdlan & 27 & 81 & 83 & 84 \\
Pachyman & 33 & 78 & 81 & 83 \\
Zymosan A & 13 & 85 & 96 & 94 \\
Lichenan & 31 & 74 & 71 & 72 \\
Cellulose & 43 & 76 & 72 & 76 \\
Xylan & 86 & 88 & 86 & 86 \\
\hline
\end{tabular}

determined (Table 2). The extent of the decrease of enzymic activity in the supernatant is an index of the binding affinity of the enzyme to the insoluble polysaccharides. No glucose equivalent was released during the $1 \mathrm{~h}$ incubation at $4^{\circ} \mathrm{C}$. In general, Curd 1 had a much stronger binding activity than the C-terminally truncated proteins to $\beta$-glucans with various glucosidic linkages. Xylan was a poor binding substrate in this case. (a)

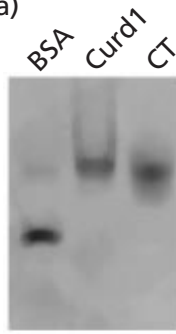

$(-)$

(c)

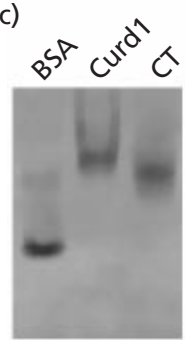

$(-)$

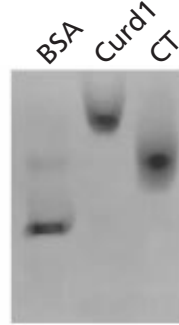

$(+)$

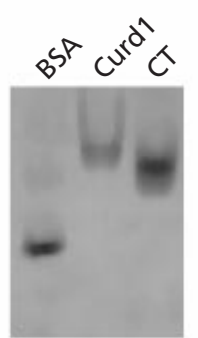

$(+)$ (b)

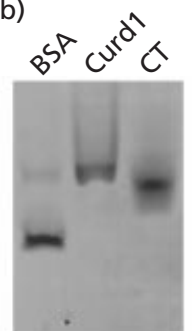

$(-)$

(d)

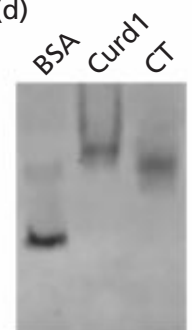

$(-)$

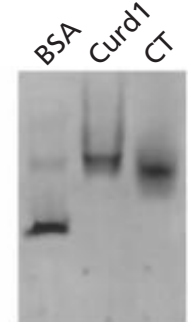

$(+)$

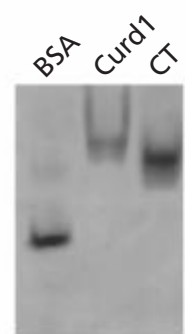

$(+)$
Fig. 5. Retardation of proteins on polyacrylamide gels containing various soluble polysaccharides: (a) laminarin; (b) lichenan; (c) CMC; (d) xylan. Samples $(2 \mu \mathrm{g})$ of bovine serum albumin (BSA), Curd1 and CT were subjected to native PAGE at $4{ }^{\circ} \mathrm{C}$ in the presence $(+)$ or absence $(-)$ of $0.1 \%(\mathrm{w} / \mathrm{v})$ soluble glycan as described in Methods. Proteins were visualized by Coomassie blue staining after electrophoresis.

In the second approach, the binding ability to soluble polysaccharides was assessed by a gel affinity electrophoresis method, in which the motility of a protein is slowed down due to its binding to the polysaccharide embedded in the polyacrylamide gel. Under the assay conditions described in Methods, laminarin slowed the migration rate of Curd1 but had no effect on CT (Fig. 5), suggesting that the $\mathrm{C}$-terminal CBM binds more strongly to laminarin than the glycosyl hydrolase domain. Curd1 did not seem to bind lichenan in this assay, inconsistent with the result shown in Table 2 . A possible conformational change of lichenan due to the heat treatment in the preparation of affinity gels may explain this incompatible result. CMC and xylan did not slow the motility of Curd1 or CT, indicating that neither the glycosyl hydrolase domain nor the C-terminal CBM binds significantly to soluble $1,4-\beta$-glucans. Taken together, the binding data indicate that the function of the C-terminal CBM is to bind to various insoluble and soluble $1,3-\beta$-glucans.

\section{DISCUSSION}

Our S. sioyaensis strain is antagonistic to several plantpathogenic fungi (Chen et al., 2000). Antimicrobial substances and enzymes such as 1,3- $\beta$-glucanase may contribute to its antagonism. In this study, a DNA fragment encoding 1,3- $\beta$-glucanase was cloned from this $S$. sioyaensis strain. According to the deduced amino acid sequence, this $1,3-\beta$-glucanase contains three func- 
tional regions : an $\mathrm{N}$-terminal leader sequence, a glycosyl hydrolase domain and a C-terminal CBM domain. A segment containing a stretch of nine consecutive glycine residues followed by a threonine- and proline-rich sequence lies between the hydrolase and the C-terminal CBM domains. This presumably flexible segment may serve as a linker connecting the two neighbouring domains. A similar linker structure has been found in the cellulase from Cellvibrio mixtus (Fontes et al., 1998). We expressed the Streptomyces enzyme in E. coli, purified it to homogeneity and characterized the respective properties of each domain.

The N-terminal leader sequence was processed properly in E. coli, and could direct the recombinant proteins into the periplasmic space. In addition to the matured fulllength protein (Curd1), two smaller protein fragments (Curd2 and Curd3) were produced. Curd2 and Curd3 are proposed to be the C-terminally truncated versions of Curd1 because all three proteins have identical $\mathrm{N}$ terminal amino acid sequences and similar activity, $\mathrm{pH}$ and temperature profiles; moreover, Curd 3 and CT had very similar apparent molecular masses, activity profiles and substrate preferences. We hypothesize that the Streptomyces 1,3- $\beta$-glucanase was subjected to attacks by E. coli proteinases at the linker region when secreted into the periplasmic space. The expression of the $1,3-\beta$ glucanase of B. circulans WL-12 (Watanabe $e$ t al., 1992) and of T. neapolitana (Zverlov et al., 1997) in E. coli cells also resulted in the production of multiple forms of the recombinant protein.

The glycosyl hydrolase domain shares sequence similarity with bacterial $1,3-\beta$-glucanases of GHF 16 (Fig. 1a) and contains a conserved GELDIME motif, whose catalytic importance has been suggested by the crystal structure of a Bacillus 1,3-1,4- $\beta$-glucanase (Keitel et al., 1993; Hahn et al., 1995), and by mutational analyses of 1,3-1,4- $\beta$-glucanase (Juncosa et al., 1994) and laminarinase (Krah et al., 1998). Two subfamilies, 1,3-1,4- $\beta$ glucanases (licheninases) (EC 3.2.1.73) and 1,3- $\beta$-glucanases (EC 3.2.1.39), are classified within GHF 16 based mainly on substrate specificity. Licheninase catalyses the hydrolysis of $1,4-\beta$-glucosidic linkages only when the glucosyl residue is itself linked at the O-3 position, whereas $1,3-\beta$-glucanase primarily catalyses the hydrolysis of $1,3-\beta$-glucosidic linkages in $1,3-\beta$ glucans. The $S$. sioyaensis glucanase efficiently catalyses the hydrolysis of $1,3-\beta$-glucans of various origins except zymosan A. In comparison to 1,3 - $\beta$-glucans, lichenan was hydrolysed at a relatively slower rate. Taken together with the enzyme's endolytic mode of action, we conclude that the glycosyl hydrolase domain should be classified as an endo-1,3- $\beta$-glucanase (EC 3.2.1.39). Similar substrate preference has been found in other bacterial 1,3- $\beta$-glucanases such as those from B. circulans (Okada et al., 1995; Yahata et al., 1990), P. furiosus (Gueguen et al., 1997), Cellvibrio mixtus (Sakellaris et al., 1990) and T. neapolitana (Zverlov et al., 1997).

The CBM of the Streptomyces 1,3- $\beta$-glucanase, dispensable for catalytic activity of the glycosyl hydrolase

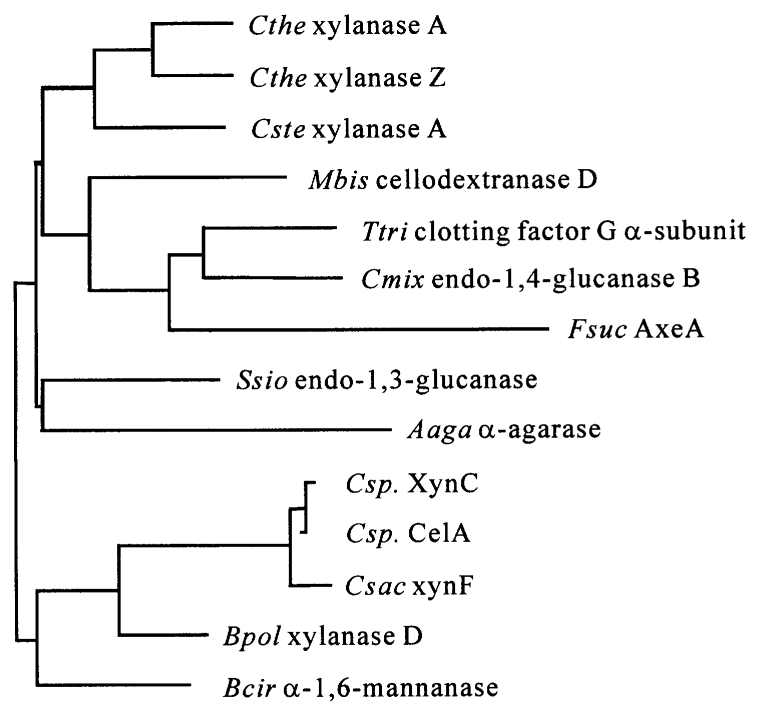

Substitution per 100 amino acids

Fig. 6. Dendrogram derived from a similarity alignment of members of CBM family 6. The tree topology was evaluated and corrected according to the results obtained from a multiple sequence alignment applying likelihood (CLUSTAL W) of the GCG program. Cthe xylanase A, Clostridium thermocellum F1/YS (AF04776); Cthe xylanase Z, Clostridium thermocellum NCIB 10682 (M22624); Cste xylanase A, Clostridium stercorarium F-9 (D13325); Mbis cellodextranase D, Microbispora bispora (L06134); Ttri clotting factor $\mathrm{G} \alpha$-subunit, Tachypleus tridentatus (D16622); Cmix endo-1,4-glucanase B, Cellvibrio mixtus (AF003697); Fsuc AxeA, Fibrobacter succinogenes S85 (AF180369); Ssio endo-1,3-glucanase, Streptomyces sioyaensis (AF217415); Aaga $\alpha$-agarase, Alteromonas agarilytica GJ1B (AF121273); Csp. XynC, Caldicellulosiruptor sp. Rt69B.1 (AF036924); Csp. CelA, Caldicellulosiruptor sp. Tok7B.1 (AF078737); Csac xynF, Caldicellulosiruptor saccharolyticus (AF005383); Bpol xylanase D, Bacillus polymyxa (X57094); Bcir $\alpha$-1,6-mannanase, Bacillus circulans TN31 (B024331).

domain on laminarin, displays a high degree of homology with the CBMs classified in family 6 (Fig. 6). In general, members of CBM family 6 are linked to the xylanase domain and bind to xylan. For example, the CBM of Clostridium stercorarium xylanase A binds xylan and plays an important role in xylan hydrolysis (Sun et al., 1998). To our knowledge, the CBM of the Streptomyces $1,3-\beta$-glucanase is the first instance of a family $6 \mathrm{CBM}$ that associates with a $1,3-\beta$-glucanase domain. Binding assays demonstrated the binding of the C-terminal CBM to insoluble $\beta$-glucans not only with 1,3- but also with 1,3-1,4- and 1,4- linkages (Table 2). The strong binding of the C-terminal CBM to curdlan and pachyman probably accounts for the increase of the specific activities of Curd1 against these insoluble substrates, presumably by increasing the frequency of encounter events between the hydrolase domain and the substrates. A similar effect has been identified for Lam16A from $T$. neapolitana in that the presence of CBM4-2 enhanced the Lam16A activity towards gelatinized and insoluble or mixed-linkage $1,3-\beta$-glucan 
(Zverlov et al., 2001). Despite not being hydrolysed by the glycosyl hydrolase domain, cellulose and insoluble lichenan could be bound by the C-terminal CBM. Polysaccharides in the natural environment could have very complicated structures containing various glycolytic linkages; therefore, with the ability to bind to various linkages, Curd1 should be able to function more efficiently in nature. With regard to soluble polysaccharide, gel-affinity electrophoresis showed a strong binding of the C-terminal CBM to laminarin. Binding of laminarin to the C-terminal CBM is non-productive from the point of view of the catalytic activity exerted by the hydrolase domain, and this may explain the slight increase of $K_{m}$ in Curd1. Soluble lichenan, xylan and $\mathrm{CMC}$ did not cause the retardation of either Curd1 or $\mathrm{CT}$, suggesting that only a weak binding occurred (if it did occur) between the C-terminal CBM and these soluble polysaccharides. In summary, the C-terminal CBM is distinct from others of family 6 as regards binding preference, especially in its reluctant binding to xylan. The structural determinants for such difference deserve to be addressed in the future.

\section{ACKNOWLEDGEMENTS}

We would like to thank Dr Ming F. Tam at Institute of Molecular Biology, Academia Sinica, Taiwan, for the determination of protein molecular mass by LC/MS, and Muthukumar Nadar for assistance in preparing this manuscript. This work was supported by National Science Council, Republic of China: NSC 88-2317-B-005-006.

\section{REFERENCES}

Altschul, S. F., Madden, T. L., Schäffer, A., Zhang, A. J. Z., Miller, W. \& Lipman, D. J. (1997). Gapped BLAST and PSI-BLAST: a new generation of protein database search programs. Nucleic Acids Res 25, 3389-3402.

Béguin, P. (1983). Detection of cellulose activity in polyacrylamide gels using Congo red-stained agar replica. Anal Biochem 131, 333-336.

Bradford, M. M. (1976). A rapid and sensitive method for the quantitation of microgram quantities of protein utilizing the principle of protein-dye binding. Anal Biochem 72, 248-254.

Bucciaglia, P. A. \& Smith, A. G. (1994). Cloning and characterization of Tag 1 , a tobacco anther $\beta$-1,3-glucanase expressed during tetrad dissolution. Plant Mol Biol 24, 903-914.

Castresana, C., de Carvalho, F., Gheysen, G., Habets, M., Inze, D. \& van Montagu, M. (1990). Tissue-specific and pathogen-induced regulation of a Nicotiana plumbaginifolia $\beta$-1,3-glucanase gene. Plant Cell 2, 1131-1143.

Chang, M. M., Culley, D. E. \& Hadwiger, L. A. (1993). Nucleotide sequence of a pea (Pisum sativum L.) $\beta$-1,3-glucanase gene. Plant Physiol 101, 1121-1122.

Chen, C. H., Huang, J. W. \& Tzeng, D. S. (2000). Development of PMS 502-Streptomyces biopesticide and evaluation of its efficacy on the control of crop fungal diseases. Plant Pathol Bull 9, 193 (in Chinese).

Chye, M. L. \& Cheung, K. Y. (1995). $\beta-1,3-$ Glucanase is highly expressed in laticifers of Hevea brasiliensis. Plant Mol Biol 29, 397-402.

de la Cruz, J., Pintor-Toro, J. A., Benitez, T., Llobell, A. \& Romero,
L. C. (1995). A novel endo- $\beta$-1,3-glucanase, BGN13.1, involved in the mycoparasitism of Trichoderma harzianum. J Bacteriol 177, 6937-6945.

de Loose, M., Alliotte, T., Gheysen, G., Genetello, C., Gielen, J., Soetaert, P., van Montagu, M. \& Inze, D. (1988). Primary structure of a hormonally regulated $\beta$-glucanase of Nicotiana plumbaginifolia. Gene 70, 13-23.

Doi, K. \& Doi, A. (1986). Cloning and expression in Escherichia coli of the gene for an Arthrobacter 1,3- $\beta$-glucanase. J Bacteriol 168, 1272-1276.

Ferrer, P., Halkier, T., Hedegaard, L., Savva, D., Diers, I. \& Asenjo, J. A. (1996). Nucleotide sequence of a $\beta$-1,3-glucanase isoenzyme IIA gene of Oerskovia xanthineolytica LL G109 (Cellulomonas cellulans) and initial characterization of the recombinant enzyme expressed in Bacillus subtilis. J Bacteriol 178, 4751-4757.

Fontes, C. M. G. A., Clarke, J. H., Hazlewood, G. P., Fernandes, T. H., Gilbert, H. J. \& Ferreira, L. M. A. (1998). Identification of tandemly repeated type VI cellulose-binding domains in an endoglucanase from the aerobic soil bacterium Cellvibrio mixtus. Appl Microbiol Biotechnol 49, 552-559.

Fried, B. \& Sherma, J. (1982). Thin-layer Chromatography: Techniques and Applications. New York: Marcel Dekker.

Grenier, J., Potvin, C. \& Asselin, A. (1993). Barley pathogenesisrelated proteins with fungal cell wall lytic activity inhibit the growth of yeasts. Plant Physiol 103, 1277-1283.

Gueguen, Y., Voorhorst, W. G. B., van der Oost, J. \& de Vos, W. M. (1997). Molecular and biochemical characterization of an endo- $\beta$-1,3-glucanase of the hyperthermophilic archaeon Pyrococcus furiosus. J Biol Chem 272, 31258-31264.

Hahn, M., Keitel, T. \& Heinemann, U. (1995). Crystal and molecular structure at $0 \cdot 16-\mathrm{nm}$ resolution of the hybrid Bacillus endo-1,3-1,4- $\beta$-D-glucan 4-glucanohydrolase H (A16-M). Eur J Biochem 232, 849-858.

Henrissat, B. (1991). A classification of glycosyl hydrolases based on amino acid sequence similarities. Biochem J 280, 309-316.

Henrissat, B. \& Bairoch, A. (1993). New families in the classification of glycosyl hydrolases based on amino acid sequence similarities. Biochem J 293, 781-788.

Hudspeth, R. L., Hobbs, S. L., Anderson, D. M. \& Grula, J. W. (1996). Characterization and expression of chitinase and 1,3- $\beta$ glucanase genes in cotton. Plant Mol Biol 31, 911-916.

Juncosa, M., Pons, J., Dot, T., Querol, E. \& Planas, A. (1994). Identification of active site carboxylic residues in Bacillus licheniformis 1,3-1,4- $\beta$-D-glucan 4-glucanohydrolase by site-directed mutagenesis. J Biol Chem 269, 14530-14535.

Keitel, T., Simon, O., Borriss, R. \& Heinemann, U. (1993). Molecular and active-site structure of a Bacillus 1,3-1,4- $\beta$ glucanase. Proc Natl Acad Sci US A 90, 5287-5291.

Krah, M., Misselwitz, R., Politz, O., Tomsen, K. K., Welfle, H. \& Borriss, R. (1998). The laminarinase from thermophilic eubacterium Rhodothermus marinus: conformation, stability, and identification of active site carboxylic residues by site directed mutagenesis. Eur J Biochem 257, 101-111.

Mahasneh, A. M. \& Stewart, D. J. (1980). A medium for detecting $\beta$-(1,3)-glucanase activity in bacteria. J Appl Bacteriol 48, $457-458$.

Mohagheghpour, N., Dawson, M., Hobbs, P. \& 7 other authors (1995). Glucans as immunological adjuvants. Adv Exp Med Biol 383, 13-22.

Nossal, N. G. \& Heppel, L. A. (1966). The release of enzyme by osmotic shock from Escherichia coli in exponential phase. J Biol Chem 241, 3055-3062. 
Oh, H. Y. \& Yang, M. S. (1995). Nucleotide sequence of genomic DNA encoding the potato $\beta$-1,3-glucanase. Plant Physiol 107, 1453.

Okada, T., Aisaka, M., Aida, K., Nikaidou, N., Tanaka, H. \& Watanabe, T. (1995). Structure of the gene encoding $\beta-1,3-$ glucanase B of Bacillus circulans WL-12. J Ferment Bioeng 80, 229-236.

Rios-Hernandez, M., Dos-Santos, N., Silvia-Cardoso, J., BelloGarciga, J. L. \& Pedroso, M. (1994). Immunopharmacological studies of $\beta$-1,3-glucan. Arch Med Res 25, 179-180.

Ryan, E. M. \& Ward, O. P. (1985). Study of the effect of $\beta-1,3-$ glucanase from basidiomycete QM 806 on yeast extract production. Biotechnol Lett 7, 409-412.

Sakellaris, H., Pemberton, J. M. \& Manners, J. M. (1990). Gene from Cellvibrio mixtus encoding a $\beta-1,3$-endoglucanase. Appl Environ Microbiol 56, 3204-3208.

Sambrook, J., Fritsch, E. F. \& Maniatis, T. (1989). Molecular Cloning: a Laboratory Manual, 2nd edn. Cold Spring Harbor, NY: Cold Spring Harbor Laboratory.

Shen, S. H., Chretien, P., Bastien, L. \& Slilaty, S. N. (1991). Primary sequence of the glucanase gene from Oerskovia xanthineolytica: expression and purification of the enzyme from Escherichia coli. J Biol Chem 15, 1058-1063.

Spilliaert, R., Hreggvidsson, G. O., Kristjansson, J. K., Eggertsson, G. \& Palsdottir, A. (1994). Cloning and sequencing of a Rhodothermus marinus gene, bglA, coding for a thermostable $\beta$ glucanase and its expression in Escherichia coli. Eur J Biochem 224, 923-930.

Sun, J. L., Sakka, K., Karita, S., Kimura, T. \& Ohmiya, K. (1998). Adsorption of Clostridium stercorarium xylanase A to insoluble xylan and the important of the CBDs to xylan hydrolysis. $J$ Ferment Bioeng 85, 63-68.

Sun, L., Gurnon, J. R., Adams, B. J., Graves, M. V. \& van Etten, J. L. (2000). Characterization of a $\beta$-1,3-glucanase encoded by chlorella virus PBCV-1. Virology 276, 27-36.
Tomme, P., Creagh, A. L., Kilburn, D. G. \& Haynes, C. A. (1996). Interaction of polysaccharides with the N-terminal cellulosebinding domain of Cellulomonas fimi CenC. I. Binding specificity and calorimetric analysis. Biochemistry 35, 13885-13894.

von Heijne, G. (1986). A new method for predicting signal sequence cleavage sites. Nucleic Acids Res 14, 4683-4690.

Watanabe, T., Kasahara, N., Aida, K. \& Tanaka, H. (1992). Three $\mathrm{N}$-terminal domains of $\beta$-1,3-glucanase $\mathrm{A} 1$ are involved in binding to insoluble $\beta$-1,3-glucan. J Bacteriol 174, 186-190.

Wood, T. M. \& Bhat, K. M. (1988). Methods for measuring cellulase activities. Methods Enzymol 160, 87-112.

Yahata, N., Watanabe, T., Nakamura, Y., Yamamoto, Y., Kamimiya, S. \& Tanaka, H. (1990). Structure of the gene encoding $\beta$-1,3glucanase A1 of Bacillus circulans WL-12. Gene 86, 113-117.

Yamamoto, M., Ezure, T., Watanabe, T., Tanaka, H. \& Aono, R. (1998). C-terminal domain of $\beta$-1,3-glucanase $H$ in Bacillus circulans IAM1165 has a role in binding to insoluble $\beta$-1,3-glucan. FEBS Lett 433, 41-43.

Yi, S. Y. \& Hwang, B. K. (1997). Purification and antifungal activity of a basic $34 \mathrm{kDa} \beta$-1,3-glucanase from soybean hypocotyls inoculated with Phytophthora sojae f. sp. glycines. Mol Cells 7, 408-413.

Zverlov, V. V., Volkov, I. Y., Velikodvorskaya, T. V. \& Schwarz, W. H. (1997). Highly thermostable endo- $1,3-\beta$-glucanase (laminarinase) LamA from Thermotoga neapolitana: nucleotide sequence of the gene and characterization of the recombinant gene product. Microbiology 143, 1701-1708.

Zverlov, V. V., Volkov, I. Y., Velikodvorskaya, G. A. \& Schwarz, W. H. (2001). The binding pattern of two carbohydrate-binding modules of laminarinase Lam16A from Thermotoga neapolitana: differences in $\beta$-glucan binding within family CBM4. Microbiology 147, 621-629.

Received 3 October 2001; revised 5 December 2001; accepted 10 December 2001. 